\title{
The Economics of Social Problems
}




\section{The Economics of Social Problems}

THIRD EDITION

Julian Le Grand

Carol Propper

and

Ray Robinson

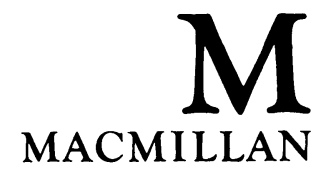


(C) Julian Le Grand and Ray Robinson 1976, 1984

(C) Julian Le Grand, Carol Propper and Ray Robinson 1992

All rights reserved. No reproduction, copy or transmission of this publication may be made without written permission.

No paragraph of this publication may be reproduced, copied or transmitted save with written permission or in accordance with the provisions of the Copyright, Designs and Patents Act 1988, or under the terms of any licence permitting limited copying issued by the Copyright Licensing Agency, 90 Tottenham Court Road, London W1P 9HE.

Any person who does any unauthorised act in relation to this publication may be liable to criminal prosecution and civil claims for damages.

First edition 1976

Reprinted 1977, 1979, 1981, 1982

Second edition 1984

Reprinted 1985, 1986, 1987, 1989

Third edition 1992

Published by

THE MACMILLAN PRESS LTD

Houndmills, Basingstoke, Hampshire RG21 2XS

and London

Companies and representatives

throughout the world

ISBN 978-0-333-55258-2

ISBN 978-1-349-21930-8 (eBook)

DOI 10.1007/978-1-349-21930-8

A catalogue record for this book is available from the British Library.

Copy-edited and typeset by Povey/Edmondson

Okehampton and Rochdale, England 


\section{Contents}

Acknowledgements xi

\section{Introduction 1}

The Problem Areas 2

Structure and Approach 3

Note to the Teacher 5

1 Social Objectives and the Allocation of Resources 7

Scarcity and Choice 8

Efficiency 9

Benefits to Consumers 10

Costs of Production 11

The Efficient Level of Output 13

Equity 15

Other Objectives 19

The Market System 20

Consumer Demand 22

Producer Supply 22

Market Price and Output 24

The Market System and Change 26

The Market System and Social

Objectives 29

Government Policies 32

Summary 33

Further Reading 33

Questions for Discussion 34

$2 \begin{aligned} & \text { Health } 36 \\ & \text { Objectives } 37 \\ & \text { Efficiency } 37 \\ & \text { Equity } 41\end{aligned}$ 
The Market System and Health Care 42

Uncertainty of Demand 43

Imperfect Information 44

Monopoly 45

Externalities 46

Equity 50

The Role of Giving 51

Government Policies 51

Regulation 52

Provision 53

Taxes and Subsidies 53

Government Policies and Objectives: an

Assessment 54

Regulation 54

Provision 55

Subsidies 56

Quasi-Markets 60

Summary 62

Further Reading 63

Questions for Discussion 64

\section{Education 65 \\ Objectives 66 \\ Efficiency 66 \\ Equity 68}

The Market System and Education $\quad 69$

Capital Market Imperfections 70

Imperfect Information 72

Externalities $\quad 74$

Monopoly 76

Equity 77

Government Policies $\quad 77$

Subsidies: Education Vouchers 79

Subsidies: Student Grants or Loans? 83

Summary 87

Further Reading $\quad 89$

Questions For Discussion 89 


\section{Objectives $_{92} 91$}

The Market System and Housing 93

Equity: Income and Access to Housing 94

Capital Market Imperfections 94

Imperfect Information 96

Externalities 97

Adjustment Problems: Supply Inelasticity 101

Government Policies 106

Regulation: Rent Control 106

Provision: Council Housing 110

Subsidies: Owner Occupation 112

The Market System and Government Policies 114

Summary 115

Further Reading 115

Questions for Discussion 116

\section{Social Care 117 \\ Objectives 118 \\ Efficiency 119 \\ Equity 121 \\ Community 122}

The Market and Social Care

Caring Externalities 123

Imperfect Information 124

Irrationality 125

Equity and Community 126

Government Policies 127

Provision 127

Subsidies 128

Regulation 129

Quasi-Markets 130

Summary 131

Further Reading 132

Questions for Discussion 133 


\section{The Environment 134}

Objectives 135

Efficiency 135

Equity 140

The Market System and the

Environment 141

Property Rights and Pollution 143

Government Policies 146

Provision 146

Regulation 147

Taxes and Subsidies 148

Pollution Rights 152

Summary 153

Further Reading 154

Questions for Discussion 155

\section{Transport 156 \\ Objectives 157 \\ Efficiency 157 \\ Equity 160}

The Market System and Transport

Externalities 161

Imperfect Information 168

Monopoly 169

Equity 169

Government Policies 170

Regulation 170

Provision 170

Taxes and Subsidies $\quad 171$

Assessment 171

Proposals for Reform 173

Congestion Taxes 174

Environmental Taxes 178

Second Best Policies 178

Summary 180

Further Reading 181

Questions for Discussion 181 


\section{The Distribution of Income and Wealth 183}

Measuring Income and Wealth 184

Measuring Poverty 184

Measuring Inequality 187

Objectives 190

Minimum Standards 190

Equality 191

Inequality 191

The Market System and the Distribution of Income 195

Differences in Resources 196

Differences in Prices 198

Insurance Failure 200

The Market and Equity 202

Summary 203

Further Reading 204

Questions for Discussion 205

\section{(9) The Redistribution of Income and Wealth 206}

\section{Taxation 206}

Taxes and Redistribution 207

Income Taxes and Efficiency 211

Social Security 212

The Negative Income Tax 215

A Minimum Wage 219

Wealth Taxation 221

Taxation of Wealth Holding 221

Taxing the Transfer of Wealth 222

Summary 224

Further Reading 225

Questions for Discussion 226 


\section{The Market and the Government 227}

The Market and Efficiency 228

The Market and Equity . 232

The Market and Other Objectives 234

Government Policy 234

Government and Efficiency 236

Provision 236

Taxes and Subsidies 237

Regulation 241

Government and Equity 242

Government and Other Objectives 244

Conclusion 245

Summary 245

Further Reading 246

Questions for Discussion 247

\section{References 248}

\section{Index 253}




\section{Acknowledgements}

Again we are greatly in debt to the many colleagues and students who have commented on earlier editions of the book and on the manuscript of this one. In particular, we would like to mention Gillian Court, Damaris Le Grand, Phillipa Marks, Robin Means, Tony O'Sullivan, Randall Smith and Christine Whitehead for helpful comments on specific chapters. A succession of editors at Macmillan have patiently endured a succession of missed deadlines without any flagging in their encouragement or commitment; the most recent (and the most patient) is Stephen Rutt. Finally, we are deeply grateful to Lorraine Cantle, who had not only to do much of the typing, but also to manage three authors and several word processors, separated geographically and often technologically. All this she did with her customary speed, efficiency and, above all, good humour.

Julian Le Grand Carol Propper Ray Robinson 